\title{
Local Environmental Politics in France: Case of the Louron Valley, 1984-1996
}

\author{
Olivier Fillieule
}

Institut d'Etudes Politiques et Internationales, Université de Lausanne, Switzerland

E-mail: olivier.julliule@jree.jr

French Politics (2003) 00, 000-000. doi:10.1057/palgrave.fp.8200016

Keywords:

\section{Introduction}

Opposition movements to big development projects have grown significantly in France since the early 1980s. ${ }^{1}$ It was the south-eastern TGV plan that started things going; protest against new infrastructures became more and more systematic, whether for transportation infrastructures (TGV, airports, extra high voltage (EHV) lines) or polluting facilities (waste incinerators, nuclear waste, landfills/dumping sites, etc.).

The rise in protest aiming systematically to challenge the legitimacy of projects was formed and developed locally through the mobilization of local actors directly interested in the defense of their environment. Planners, soon followed by researchers, referred to these fights as NIMBY, the invention of this acronym standing in for true analysis. The real danger for political science to have taken over this dismissive expression will be brought up later. For now, suffice it to say that it has worked as a smokescreen, something preventing the consideration of these fights fanning out from the local level but which tend, well beyond, to lead to a lasting and deep redefinition of the balance of powers among the various levels of the State (administrations and elected officials), planners, and the civil society; it is thus impossible to see these local battles as merely a local affair.

One hypothesis here is that focusing the analysis on local fights makes it possible to question the tools and conclusions that the sociology of social movements now has at its disposal. Likewise, the analysis of local public policies and the sociology of local party circles has been, more generally, very instructive on the way in which public policies (Mabileau, 1993) and the sociology of political parties (Sawicki, 1997) have been implemented. 
This paper stresses the study of local mobilization to show first how development conflicts have produced a definite change in the forms of public debate and the ways public policies have been implemented. In other words, not only does the State, through the systems of structuring society it defines, contribute to defining a field of possibilities for movements (McCarthy et al., 1991), but the movements themselves can spark a change in the political rules of the game. From that point of view, the field of environmental movements represents one of the best vantage points for anyone interested in the outcomes of social movements (Giugni et al. (1999) on outcomes; Della Porta and Rucht (2002) on environmental campaigns).

Secondly, it is worth taking a fresh look at certain 'commonplace notions' in the sociology of social movements through the prism of local conflicts. First of all, the classic definition of contentious politics - which in the literature is based on a distinction between insiders and outsiders, challengers and elites, civil societies and the State - is contradicted here by the complexity of the interdependences at work - how the fields of alliances and conflict are locally constructed. More generally, in the same spirit as the work on the policing of protest (Fillieule, 1997; Della Porta and Reiter, 1998), it is the very definition of the State, in its substantialist version, that is challenged. Secondly, the observation that in environmental conflicts there is a deep change in protest action repertoires put back on the agenda of disciplinary debates the question of the reception of information, in particular through the protest event analysis method, which is most often based on the identification of modes of action that have largely been either replaced or at least supplemented by an 'expert' repertoire of action to which the press pays no attention (Fillieule and Jimenez, forthcoming).

Finally, and in conclusion, the analysis of planning conflicts at the local level is a plea to enrich the research tools by taking into account recent analytical work on public policies, with, in particular, the conceptual tools of policy networks and advocacy coalitions.

This paper deals with the conflict that unfolded in the Hautes Pyrénées from 1984 to 1996, the project for an EHV line between France and Spain that was to go through the Louron Valley. After briefly relating the conflict itself emphasis will be placed on the cognitive dimension of the mobilization by analyzing first the way in which the mobilized groups tried to define a framework of interpretation of the affair so as to guarantee mobilization, and second, the specific constraints that single-issue fights run into. In this type of conflict, the definition of multi-organizational fields is made more complex vertically by the intermingling of local and national actors, and horizontally by the political-administrative sphere and the civil society, and also by the redefinition of the State's methods of opposition management, under the very effect of mobilization. 


\section{The Louron Case}

\section{The birth of a development project}

The present interconnection grid between France and Spain consists of five trans-Pyrenean lines. Two of them are EHV lines. Since 1976, EDF has been studying the possibility of increasing the export of its electric energy to Spain. The construction of a sixth trans-Pyrenean line was part of the scheduled increase in transmission capacity in the region to be achieved by putting the Golfech (Tarn-et-Garonne) nuclear plant into service. EDF presented the planned $400 \mathrm{kV}^{2}$ circuit EHV line joining Cazaril-Tambourès on 20 January 1984. The line crossed the Neste, Nistos and Louron valleys on the French side and the Taberes and Gistain valleys in Spain. It was to be $273 \mathrm{~km}$ long with $60 \mathrm{~km}$ on the French side and $185 \mathrm{~km}$ on the Spanish side. For EDF the project was the contract of the century, as the sale of electricity to Spain and Portugal was expected to bring in close to 2 billion francs a year.

The decision to build the line was ratified in July 1984 by a ministerial committee that chose the Louron route after a quick look at other routes even though the Minister of the Environment at the time, Huguette Bouchardeau, opposed it and a previous ministerial committee had adopted the principle of putting the Louron valley on the historical register. ${ }^{2}$ From that moment on, EDF had a clear path, and in the summer 1984, technicians were sent there to prepare the ground. ${ }^{3}$ However, there was immediate resistance, paving the way for the Louron Valley EHV-line saga to begin. It ended 12 years later, in December 1996, with the project being shelved.

\section{Act One: September 1984-April 1989}

Regional governments set the opposition to this development project in motion. The Midi-Pyrénées DRAE, backed by the Secretary of State for Environment, persisted in attempting to register the Louron Valley - a process begun in 1982 - thus hoping to derail the project.

At the same time, once the process was launched, the DRAE would point out the many irregularities and omissions of the impact study (April 1985). Even before the definitive choice of the line, the DRAE had suggested another one, through the Aran valley, endorsed by the National Office of Forests (ONF). The project was not accepted, however, for at least three reasons: the King of Spain indicated that he was against this route because it was too near the Baqueira-Beiret ski resort he patronized. The route would necessitate lengthening the Spanish side of the line, an additional cost France refused to pay for. Lastly and above all, this route went through Catalonia, and the Spanish government feared a mobilization of autonomists. The Aragonese solution turned out to be the least risky. 
The civil society reacted through its local elected officials who attempted to impose a different line. A multi-party defense committee was set up in August 1984, composed of mayors, general councilors, two deputies and the Senator and Mayor of Lourdes. The committee also included Michel Geoffre, regional councilor and president of Bigorre Ecology, and trade union delegates from the FNSEA and CDJA, two farmers' unions, as the farmers were showing signs of worry. The first move of this committee was to complain to the Regional Council and to write to the prefect asking him to have the State re-examine the proposed route. A different solution was defended.

At this stage, the mobilization was essentially institutional, with a few regional administrations on one side and, on the other, elected department officials who immediately complained about not being consulted either by EDF or by the government. At the same time, on the Spanish side, the same type of mobilization of local elected officials gathered steam around the plan to create a national park.

Ten months later, in June 1985, whereas neither EDF nor the government had in any way broached the subject, environmental protection associations took up the issue; or rather, because the volunteer leaders were largely the same locally elected officials already mobilized, it was within the framework of volunteer organization mobilization that the mayors and regional councilors would organize. The strategy adopted was two-fold: First, thanks to the work of experts, the environmentalists put themselves on EDF's terrain by suggesting alternative solutions that were less harmful for the environment; secondly, by counting on the mobilization in progress on the Spanish side, they made a show of strength by organizing demonstrations and securing media coverage.

First, the involvement of experts. In June 1985, the COPRAE (Permanent Regional Council of Environmental Associations, Midi-Pyrénées) published a report that put forward two alternative solutions (the reinforcement of existing lines and the proposed route of the Aran valley). At a press conference on 7 April 1987, UMINATE presented a new line plan through the Boucharo pass, near the Gavarnie.cirque. Not only did the proposal provide all the guarantees of reliability and expertise, but also Michel Geoffre, the president of UMINATE, announced that the local officials of the Valley of the Luz, Gavarnie, approved the line as did the DDE and there would be no opposition of the western National Pyrénées park board (Gavarnie).

Resorting to a show of strength, secondly. The first demonstration, called by the COPRAE and the ecologists on 16 July 1985, gathered few people. It was in Arreau, on the path of the Tour de France. This was when contacts between French and Spanish associations were made, leading to an annual FrancoSpanish demonstration. The first one took place on 19 August 1985 in Génos, in the Louron and gathered at most 500 people, most of whom came from 
Spain. On 23 August 1986, the second demonstration took place at the entry to the Aragnouet tunnel: there were 200 people, mostly Spanish again. On the French side, the few dozen demonstrators were local officials and members of volunteer associations. However, for the first time, SEPANSO, the regional federation of environmental associations, was present, showing that general mobilization was gaining. Then on 13 August 1988, the demonstration took place at Loudenvielle with 30 French people and 200 Spanish. A 'no pasaran!' sign was put up before a 3 -h march ending in a press conference.

On 26 August 1988, the minister of industry, Roger Fauroux, declared that the EHV line was of public interest. The way seemed clear for the construction permit to be signed and the work to begin. However, after a trip to the valley of the Louron, the minister postponed the decision on 12 April 1989. The Greens' intense lobbying and especially the unanimous mobilization of all the elected officials made him back down. He himself was from Tarbes and mayor of Saint-Girons. In fact, the project was not abandoned; EDF was simply asked to make new studies of the proposed lines. The decision to back down was probably because of EDF's stubborn refusal to discuss or negotiate alternative solutions.

Finally, on 15 December 1989, the minister reinstated the public interest declaration. EDF came up with a study in which the Gavarnie solution was declared invalid and proposed instead, in exchange for the EHV in the Louron, to bury the part of the $220 \mathrm{kV}$ that passed through the Gavarnie park. At the same time as his decision, the minister also announced a study mission to the National Assembly on the best way to provide electricity in their environment and the necessary improvement of administrative procedures to guarantee dialogue. Associations and local officials were to be included in this mission.

\section{Act Two: December 1989-November 1991}

The battle seemed to be lost when the environment minister, Brice Lalonde (Génération Ecologie), joined in the fray and said, on 22 December 1989, that there would be a study on registering the Valley of the Pez as protected land. This study automatically delayed the beginning of the work for 1 year. The decision directly contradicted the industry minister's decision and angered Matignon, the Prime Minister's office. Brice Lalonde was asked to withdraw his procedure. He refused and called for arbitration at the highest level. On 16 March 1990, the departmental commission of sites gave its agreement to registering the upper valley. However, on 29 March, the case was stopped by Matignon. On 30 May Brice Lalonde gave in and agreed to the EHV line. The construction permit was granted by the Hautes-Pyrénées prefect on 13 June and on 4 July, the minister approved the project and gave the green light for work to begin. 
While the environment ministry was seeking ways to block the work, the mobilization of the associations and the officials continued. The associations' strategy shifted to the legal sphere. A Paris law firm specialized in environment questions was brought in. Huglo-Lepage had defended the victims of the Amoco-Cadiz oil spill. The battle would focus on the substance of the project and on legal irregularities so as to delay the beginning of the work. In January 1990, the collective to save the Pyrénées (CSP) referred the industry minister's decision authorizing the work to the Conseil d'Etat for abuse of power. In addition, on 9 August 1990 the Huglo-Lepage firm filed a suit in the administrative court of Pau against the prefectoral decision of 13 June, in which the prefect of the Hautes-Pyrénées had granted the construction permit. Entering the legal battle did not preclude traditional forms of mobilization, and the annual demonstration of 29 August 1990 at the Génos lake gathered 22 French and nine Spanish associations, with participation of several hundred people, mostly Spanish. That was also the day the Greens demonstrated in Lourdes, reported in Le Monde on 31 August 1990. ${ }^{4}$

Mobilization of the officials was intensifying mainly through the unanimous commitment of the Midi-Pyrénées regional council with the Hautes-Pyrénées general council and mayors. The general council of the Hautes-Pyrénées ordered a feasibility study from Omnitech, an independent Palois firm, for an EHV line with underground direct current cable (costing more than 120,000 FF); it also suggested to the government that it begin talks with EDF, the representatives of the Hautes-Pyrénées, the region, the Aragon and Catalan officials. On 16 October 1991, a motion was passed to demand the end of the project. Increasing mobilization among elected officials could also be measured by the participation of people like Dominique Baudis, Toulouse's deputy mayor, who in April 1991 put a written question to Michel Rocard, Prime Minister, about the EHV line; Antoine Waechter, the Greens' spokesman, demanded the Brice Lalonde's resignation because 'by remaining in the government, you've been the accomplice of the massacre of two splendid valleys as well as of disastrous energy and road choices for the country' (16 September 1991). Lastly, Marc Censi, UDF representative, requested a meeting with the minister of industry along with UMINATE.

Confronted with the mobilization of the region's representatives from all sides, the answer of the new minister of industry (Dominique Strauss Khan) was first to demand a new examination of the case, pretexting the need to 'go around once more before starting the work' (10 July 1990). Not that an alternative solution was being envisaged, but this was simply a way to make up for the lack of dialogue and consultation. In fact, early September 1991, the minister authorized the project. However, the associations made the claim that the DUP and the construction permit were awaiting a court decision from the Conseil d'Etat and the court of Pau and that it was out of the question to begin 
work before these decisions were handed down. François Mitterrand's intervention supporting the suspension was decisive. Nothing happened until 5 November 1991 when Pau's administrative court pronounced the indefinite postponement of the construction permit. The associations shouted victory. EDF announced an appeal before the Conseil d'Etat that now had to judge the whole case: EDF's appeal, the validity of the construction permit and the declaration of public utility. Brice Lalonde flew over the valley of the Louron by helicopter and declared to the journalists that it was very beautiful and shouldn't be touched.'

\section{Act Three: January 1993-December 1996}

As of 1993, the situation had changed considerably in that the government was more and more wary of the project. There was the rising mobilization for the tunnel of Somport, and Balladur, the prime minister, wanted to avoid another front at all costs. Moreover, a national debate on energy was to take place, and Michel Barnier, minister of the environment, stated that regardless of the Conseil d'Etat's decision, the results of this debate had to be taken into account before beginning the work (June 1993). Thus, after the Conseil upheld EDF and ratified the DUP (29 April 1994), Matignon also said it was necessary to wait for the national debate (May 1994). However, when it occurred, in December 1994, the Souviron report came out in favor of the project, albeit denouncing EDF's lack of transparency and the democratic deficit that pervaded the whole affair.

While the government was stepping back, the associations and local groups continued to wage war on the legal front. In January 1993, the CLEMP (MidiPyrénées coordination of electric lines), a regional federation of associations, was created that aimed to combat several proposed lines, basing itself on the 'lines' protocol signed between the government and EDF on 25 August 1992, stipulating that wherever new routes were envisaged, dialogues and an examination of alternative routes be put in place as well.

As far as the territorial groups (general and regional councils) and UMINATE were concerned, in June 1994 they undertook a new move at the Pau administrative court to annul the construction permit and filed an appeal before the European Commission in Brussels on the basis of article 169 and before the European Court of Justice for non-respect of community law in administrative investigation of trans-frontier projects. On 6 January 1995, the Pau court canceled the permit. EDF appealed the decision before the Bordeaux administrative court. The case was judged on 14 December 1995 and EDF won.

The legal battle was lost. One last demonstration was organized for one last attempt at pressure. On 26 January 1996, 200 people demonstrated against the 
Minister of the Environment, Corinne Lepage, at the closing of the regional Environment and Sustainable Development conference that was held in Tarbes. At the same time, the associations and elected officials, represented by Michel Pelieu, (general councilor, Hautes-Pyrénées) publicly requested arbitration at the highest level. Michel Pelieu addressed an open letter to Alain Juppé (Prime Minister and mayor of Bordeaux), Corinne Lepage, Philippe Douste-Blazy (Culture Minister) and Borotra (Industry Minister) in which he recalled that there was an ongoing suit in Brussels as well as an appeal following the Bordeaux administrative appeals court decision. Since none of these actions suspended the project, he asked the government to freeze the plan. On 25 January, Alain Juppé met with Michel Pelieu for 15 min, in the presence of Philippe Douste-Blazy, mayor of Lourdes and minister of culture.

On 1 February 1996, Alain Juppé, visibly moved, declared to the National Assembly during question time that he was definitively burying the EHV line question: 'I am shocked when I see these unique landscapes desecrated by the EHV lines, carried by very high pylons, irrevocably harming the environment.' On 6 February, he made a flash visit to Louron: Enthusiastically, he said to the press: 'I've chosen the environment, democracy and the development of the territory. We must change our way of governing because we can no longer take decisions that the people are against. Here, you are carrying out a policy of development and protection of the symbolic sites for a better territorial balance, and the government will help within the framework of support of rural development.' On 7 February, he proposed registering the Louron Valley as national heritage, effective on 18 December 1996. The valley was saved. EDF had to find alternative solutions to fulfill its contract signed with Spain.

\section{Grievance extension, cultural resources and action repertoires}

The literature on land development conflicts has been a key factor in introducing the cultural and cognitive dimension into the classic perspective of resource mobilization via the attention given to how organized groups redefine the very terms of the fight. Two issues have been studied extensively: one concerning the sociology of social problems (Gusfield, 1986), the way in which environmental groups have endeavored to construct reference frameworks as alternatives to the dominant one of technological progress and economic development in order to defend the idea of sustainable development and respect for the planet's natural landscape and resources. As Fabiani emphasized, 'there is no consensus around nature; the conflict on contradictory social uses of natural space is a given and the notion of the protection of nature is a stake in the fight among social groups' (1986). The literature on this subject has highlighted the crucial role of grievances and their rhetorical use in the formation, activities and chances of success of protest groups. ${ }^{5}$ 
The other issue has to do with the particular constraints that territorialized fights have come up against, in other words single-issue, geographically localized battles (Gordon and Jasper, 1996). How do protest groups manage to globalize their rhetoric to mobilize outsider groups and public opinion through the media, and to justify their fight in the name of the same general interest that the authorities claim and that the groups are opposed to? This constraint of frame extension refers to the labeling of development conflicts in terms of NIMBY as an attempt at disqualification. The expression was coined by American planners who had a vested interest in delegitimizing the protests of their development projects. To refer again to Pierre Lascoumes, 'it is important to see that when an association is criticized for being merely a manifestation of the NIMBY syndrome, it is usually made by the companies or administrations doing the developing, trying to disqualify these groupings of 'marginals' against technological progress and looking out for more cooperative interlocutors' $(1994,233)$. The thrust of the term NIMBY is to produce a dichotomy between the rights of citizens (thought to be of the same mind as the general interest through the choice of their representatives) and those of the inhabitants, necessarily invested with individual and selfish interests. ${ }^{6}$ Here, following the helpful suggestion of Jobert (1998), the term 'development conflicts' will be used.

The Louron Valley case provides a typical and ideal illustration of the way in which protest groups attempt to raise the stakes of their cause to counteract the delegitimation of them in the name of the general interest and to gather around them, collective actors and individuals who are not directly concerned.

In the first phase of the conflict (1984-1989), the main argument stressed the exceptional value of the landscape and heritage of the Louron Valley. ${ }^{7}$ As of 1984, the DRAE established the terms of this argument by not only defending the idea that the valley represented an original preserved entity through its relative isolation in geographical and landscape terms, but also because of the preservation of the built environment. The Louron Valley was presented as the archetype of the 19th century Pyrenean valley. The strength of this line of argumentation lay in its being labeled from the beginning as the 'conflict of Louron,' even though the proposed line also went through the Neste and the Nistos valleys. The Nistos valley is a 'territory without qualities,' in Bernard Kalaora's words (1981). In the eyes of the Pyrenean specialists who were helping to create the image, it was devoid of worthwhile features. In the press, though, this valley was presented not only as a 'green and mossy gem' ( $L e$ Monde, 20/08/85) but also as the 'cousin' of the Louron valley, the one that did have a geographical and cultural entity. This rhetoric of landscape and cultural heritage defined by DRAE dismisses the NIMBY reference by invoking a universal common good, basing it on the 1982 proposal to register the site of the valley. At the same time, the rhetoric of the common good entitled 
opponents to make suggestions typically qualified as NIMBY by public authorities and the media, that is, shifting the proposed routes to other places. This operation was facilitated in that the first route through the Aran Valley, less harmful ecologically, was agreed upon until the King of Spain decided against it for his own personal interest. The protesters would have had an easy time turning the accusation of playing into the hands of special interests against the government and EDF. The local officials would adopt the rhetoric of the common good but link it to an economic rhetoric: the preservation of Louron's cultural heritage would also serve their interests since the valley represented a unique worldwide tourist mine. However if tourism was to help fight the exodus from the valleys and lead to lasting job creation, the EHV line would jeopardize all of those efforts. Through this frame extension, the elected officials were both defenders of the landscape and inhabitants of the valleys while claiming to be more realistic than the ecologists who were stigmatized as unrealistic dreamers. ${ }^{8}$ The use of economic rhetoric is also helpful in questioning the substance of the project. The officials and soon the associations pointed out that if it was deemed necessary to sell current to Spain (that would be sold at a loss), it meant that the construction of the Golfech nuclear plant in 1982 was actually unnecessary and that the aim was really to sell off the resulting overproduction. The infernal logic in which energy planning mistakes had to be paid for twice was denounced.

Lastly, a third field on which the mobilization was played out in this first period was that of participation rhetoric. Local officials felt betrayed by the government and EDF because they were never consulted on the project. They denounced the absence of transparency of the procedures and the scorn of 'national representatives.' A turning point in the protesters' strategy was reached in 1988 in that procedural rhetoric was becoming central and was used increasingly (Gordon and Jasper, 1996). Thus, the fight was shifting to the legal field, the stakes being to delay the start of the work as long as possible once the environment ministry failed to get the site registered.

Three new points were added to the argumentation:

(1) On the one hand, the mention of European directive $85 / 337$ on environmental protection and electrical energy transportation projects that were not taken into account by the developers; on the other hand, the complaint filed at the Conseil d'Etat by the CSP in January 1990 against the industry ministry's decision authorizing the work and against the prefectoral decision delivering the construction permit (August 1990).

(2) Then the UMINATE association sought in the cadastral archives as a way to disqualify the redefinition of the zoning plan. Thus, during the summer of 1990, UMINATE unearthed three cases to try to invalidate the construction permit: the illegal building of the cross-country ski resort Nistos-Cap-Nestès, 
bringing to the fore an old problem having to do with a $7 \mathrm{~km}^{2}$ piece of land that was to have received several pylons. Even more, it was EDF that partially financed the construction of the resort to get in the good graces of the towns involved. In a press release in August 1988, the group of associations accused EDF of carrying out 'an aggressive development policy for the natural surroundings by buying, if necessary, the agreement of individuals or local governing bodies concerned by its projects... The Nistos cross-country ski stadium is the obvious example of this influence and money peddling. It was built on a virgin site, already one of contention between Nistos and Sarrancolin, with no administrative authorization, no construction permit, largely financed by EDF, with the support of the prefectoral services that we had alerted several times to get them to intervene.'

(3) Lastly, the fact that the access route to the ski resort and the route of the line would cross the Nistos protected forest, registered by a presidential decree of 22 March 1927. These affairs were in administrative appeal. Josette Durieu, the general counselor of the canton of the Neste valley, was violently attacked by the associations because she negotiated directly and secretly with EDF to finance the resort and various other facilities in exchange for the passage of the line. The use of procedural rhetoric is enhanced by the denunciation of collusion among special interests under the cover of general interest.

The government reacted to this outburst of legal cases by trying to answer the participationist rhetoric while defending the economic and technical opportunities of the project. On 14 June 1994, for example, the HautesPyrénées prefect visited Louron and announced 'a national debate on energy and environment that will deal with the issues of national political development of electricity and the impact of electric lines. Everyone will be able to express his observations on these issues.' During this debate a few months later in December 1994, while defending the possibilities of the project, the Souviron report noted a 'general feeling of a democratic deficit in the establishment and implementation of energy decisions.... Transparency demands that any decision in infrastructure needs must be preceded by an independent expertise.... These principles have to be applied with special attention in the case of trans-frontier electric lines. The project of the EHV line is exemplary: more dialogue would certainly have prevented the present blocked situation'. The strategy was obviously to divide the front of the opponents by winning the favors of the elected locals, finally recognized as legitimate representatives of local public opinion. Too late, this strategy failed and the legal battle would gather steam; the CEE (as of June 1994) called for an extension of the conflict until the final victory in February 1996.

On the whole, looking at the Louron Valley affair suggests four types of argumentation the protesters have at their disposal to publicize their cause and 
which were implemented in the major development conflicts in the last 20 years: conflicts concerning the TGV (Lolive, 1999; Blatrix, 2000), the EHV lines (Remy, 1995; Leborgne, 1999) and more generally (Catherin, 2000; Larue, 2000). Table 1 summarizes them.

Local rhetoric is based on the defense of a site in the name of quality of life for the inhabitants and feared or expected environmental problems. Neither the project itself nor the technical choices accompanying it are called into question. The problem lies solely in the choice of location, rejected by the inhabitants. The only alternative rhetoric in this case is a change in the planned line.

The common good rhetoric functions according to the same territorial principle as local rhetoric, but it raises the stakes by elevating the site concerned as a cultural, registered, heritage. This case also must be solved by alternative planned lines.

Global rhetoric refers to two generally linked aspects: scientific-technical protest and economic protest. The first one tries to challenge the worth of a development project that is harmful in all cases. In the case of the EHV lines, there are public health risks (leukemia, accidents), the need to make underground installations, etc. The second one implies advocating either to give up the project or to adopt alternative technical solutions.

Procedural rhetoric resides in the denunciation of law breaking and the collusion between the government and sector-based or private interests. Gordon and Jasper defined it as: "procedural rhetoric refers to the validity of decision-making procedures rather than the direct merits of the target. ... Local protestors ... often develop a rhetoric that concentrates on abuse of power, lack of official accountability, or cozy relations between business and the state.' Spector and Kitsuse $(1987,151)$ say: 'As a consequence, assertions about the inadequacy, inefficacy, or injustice of the procedures may themselves become the conditions around which new social problems activities are organized' (Gordon and Jasper, 1996, 163). In the Louron affair, the denunciation of EDF as a state within a state considering itself above the law and endeavoring to corrupt both elected officials and individuals by buying their agreement falls within this rhetoric.

Lastly, participation rhetoric has to do with the denunciation of a lack of democracy, the obvious scorn for local officials, legitimate representatives of the citizens, and the lack of direct citizen input. This aspect will be dealt with again in the last part of this text concerning the change in the paradigm in public policies in France under the effect of development conflicts.

Table 1 suggests a link of dependence between types of justification and ways of action. It is true that rhetoric and action strategies are highly interdependent. Much literature has shown the extent to which grievances play a role in the definition of the activities of protest groups (e.g. Walsh, 1981; 
Table 1 Types of justifications for opposing a zoning plan

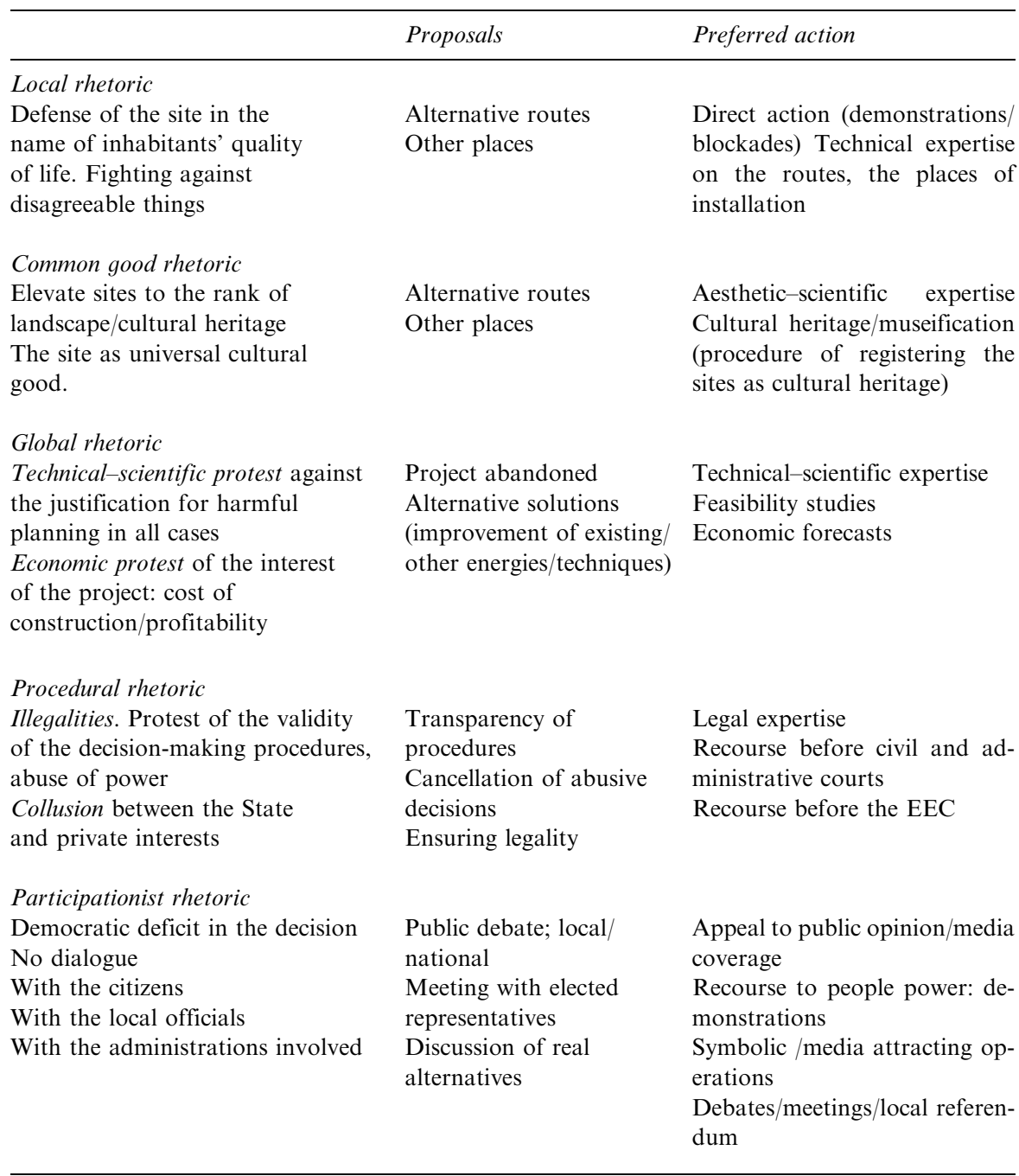

Gamson, 1992; Jasper, 1997). This also means that the different justification types can only be mobilized under certain resource conditions. The Louron affair is exemplary from this point of view as well. Table 1 shows that each form of rhetoric corresponds to a specific type of action. The common denominator of these modes of action, apart from street demonstrations that never played any role at all in this affair, is that they all necessitate more or less expensive forms of expertise, which poses the problem, mentioned elsewhere, of 
the 'expertification' of environmental activism and the way in which 'financial resources are used to promulgate ideologies and injustice frames, and how cultural meanings and rhetoric shape the definition and accumulation of financial resources' (Gordon and Jasper, 1996, 161).

The studies on alternative lines (here the two Aran Valley projects and then through the Boucharo/Gavarnie pass), the scientific justification of registering the site as cultural heritage (given the presence of plant and animal life to protect, for instance), feasibility studies for alternative procedures (underground lines, underwater cables, reinforcement of existing high voltage lines, etc.), economic forecasts aimed to contradict those put forward by the developer, the possibility of filing suits on the administrative, civil and European levels, all this requires considerable resources, both financial (here the local bodies paid for the studies, the hiring of a law firm) and human. One of the striking aspects of development conflicts is how protest associations solicit and use skills and competence people have acquired elsewhere in the professional field: retirees who have had high-level positions, engineers, university professors, etc.

More than in other areas, in this type of locally situated conflict, the effectiveness of the protest depends on the ability to publicize the cause. As Jobert has stated: 'constituting audiences for zoning cases goes hand in hand with media coverage of these questions; even though they are usually limited to local media, and are even relegated to local editions of the regional press, they introduce zoning into political communication. In the context of the fight for access to media coverage in which David is pitted against Goliath, most of the exorbitant means at the disposal of the public authorities turn out to be highly limited, even if its legal resources remain intact' $(1998,77)$. Added to this is the fact that the participationist rhetoric does not stand a chance of being effective without an audience that contests the limited deliberations among decision-makers.

It is therefore important to mention that in the early years of the conflict the local media (La Dépêche du Midi and La Nouvelle République) gave first billing to EDF's and the prefectoral administration's arguments, but they soon and unambiguously turned to support the protesters. In the first period, for example, EDF press releases and information meetings were reported without any critical objectivity. Then, as of 1989 , the situation changed and the press published in full the associations' press releases while systematically emphasizing the sound grounds of the fight. It is known that the data available on local media and environmental conflicts suggest that environmental groups tend to enjoy qualitatively greater local media access, at least for certain issues (Moloch and Lester, 1975; Freidman et al., 1987; Sandman et al., 1987; Spears et al., 1987; Singh et al., 1989; Cottle, 1993; Anderson, 1997; Fillieule and Jimenez, forthcoming). Beyond this rule, the deep reason for the local press's rallying to the cause was that the population (and thus the 
potential clientele) was totally behind the cause, as were the elected officials as a whole, with whom, obviously, the links of interdependence were evidently very tight. For example, the conflict was very different in the Somport case. There the people mobilized were considered as 'foreigners' or 'imposters' and local press support was no longer obvious.

On the national level, lastly, it is also significant that Marc Ambroise Rendu, Le Monde's journalist specialized in the environment (see Fillieule and Ferrier, 1999), made his support of the protesters' naturalist arguments very clear in the few articles that he wrote on the conflict. Likewise, the local AFP correspondent was neutral at first but soon joined the protesters' camp. As of the 29 August 1990 demonstration, mention of the technical aspects of the project (EDF speech) was superceded by a systematic reminder of the project's harmful environmental consequences:

'The villages of the valley where hay is still cut by hand but where a discrete form of tourism suitable for the environment has developed have been organized against this line for a long time. The line is supposed to run along the side of the mountain and, with its 60 to 80-meter pylon, will mar the exceptional landscape whose registry as cultural heritage is now suspended' (AFP, 8/25/1990).

Partiality reached a height in a 6 January 1995 250-word report that was supposed to cover EDF's appeal of the administrative court's decision. After a brief summary of the facts, the report stressed the 'enormity,' and thus the illegitimacy of the project: 'the project calls for the use of $8 \mathrm{~cm}$ cables help up by 90 140-ton pylons measuring at most $61 \mathrm{~m}$ high.'

\section{The State in Pieces: Advocacy Coalitions, Changing Paradigms and the Transformation of Public Policies}

The Louron affair provides a paradigmatic example of the way in which development conflicts contribute to challenging common perceptions of French polity, but more generally also of the investigative value of concepts and traditional ways of doing the sociology of social movements. The development conflicts of the last 15 years question the common but unrealistic distinction between State and protest organizations, and particularly in the case of France, frequently viewed solely as an all-powerful central State in opposition to civil society. Since the mid-1980s and the effective implementation of decentralization legislation, because of the effective transfer of a certain number of central State prerogatives to local authorities and, finally, of the increasing withdrawal of the welfare state, it is no longer possible to present things so simplistically. Beyond the case of France, moreover, the conflict 
analyzed here illustrates the extent to which traditional conceptual tools are increasingly inadequate to deal with a number of transformations that have in recent years affected the relation between State and society. As Kennis and Schneider (1991) point out, "the growth in number of "organized local authorities," the growth in number of political actors implicated in the process of public policies, the intensification of sectoralization and differentiation of policies and administrations, the proliferation of forms of "private government," the "transnationalization" of national policy - all these contribute to a profound change in the way in which we can think through the issue of collective action and contestation' (Fillieule and Ferrier, 2000). See also Fillieule (1997) and Fillieule and Ferrier (1999).

After briefly reviewing the nature of the coalitions that led to the constitution of the multi-organizational field of the opponents to the line, which leads more generally to questioning the classic split between insiders and outsiders, challengers and the State, we will show how, influenced by the development of protest to big projects, the public development policies have changed, contributing to a lasting modification of political opportunities for environmental movements (see Chart 1).

In the Louron affair, first certain components of the administration got organized, followed by the local officials and then by the environmental associations, either pre-existing or created for the occasion. This situation is one of the common characteristics of all development conflicts in the last 15 years. There is an astonishing blurring of frontiers with conflicts that join at several levels and transversally at the State/civil society cleavage: conflicts between the ministry of the environment and the ministry of industry; conflicts between the central government and regions, departments and towns through the mobilization of regional, general and municipal councils; conflicts among administrations, whether deconcentrated or decentralized, which replicate the first two conflict axes. There are three observations that can be made: (1) There is great heterogeneity of the actors in the fields of alliance and conflict: elected officials, associations, administrations and public and private companies alike can find themselves united. In most cases, the coalitions formed around locally situated conflicts generally tend to network around the ministry of environment, officials and associations. (2) The coalitions thus formed transcend partisan cleavages. In the Louron affair, it is worth noting that the MidiPyrénées Regional Council and the Hautes-Pyrénées General Council, as well as the mayors of the valleys, were unanimous in their protest against the EHV line. (3) Lastly, the heterogeneity of the actors must be balanced by the existence of complex forms of multipositionality. The officials are simple members or leaders of environmental associations and sometimes inhabitants whose personal interests are directly affected by the development projects. Industry ministry civil servants are generally alumni of the same institutes as 

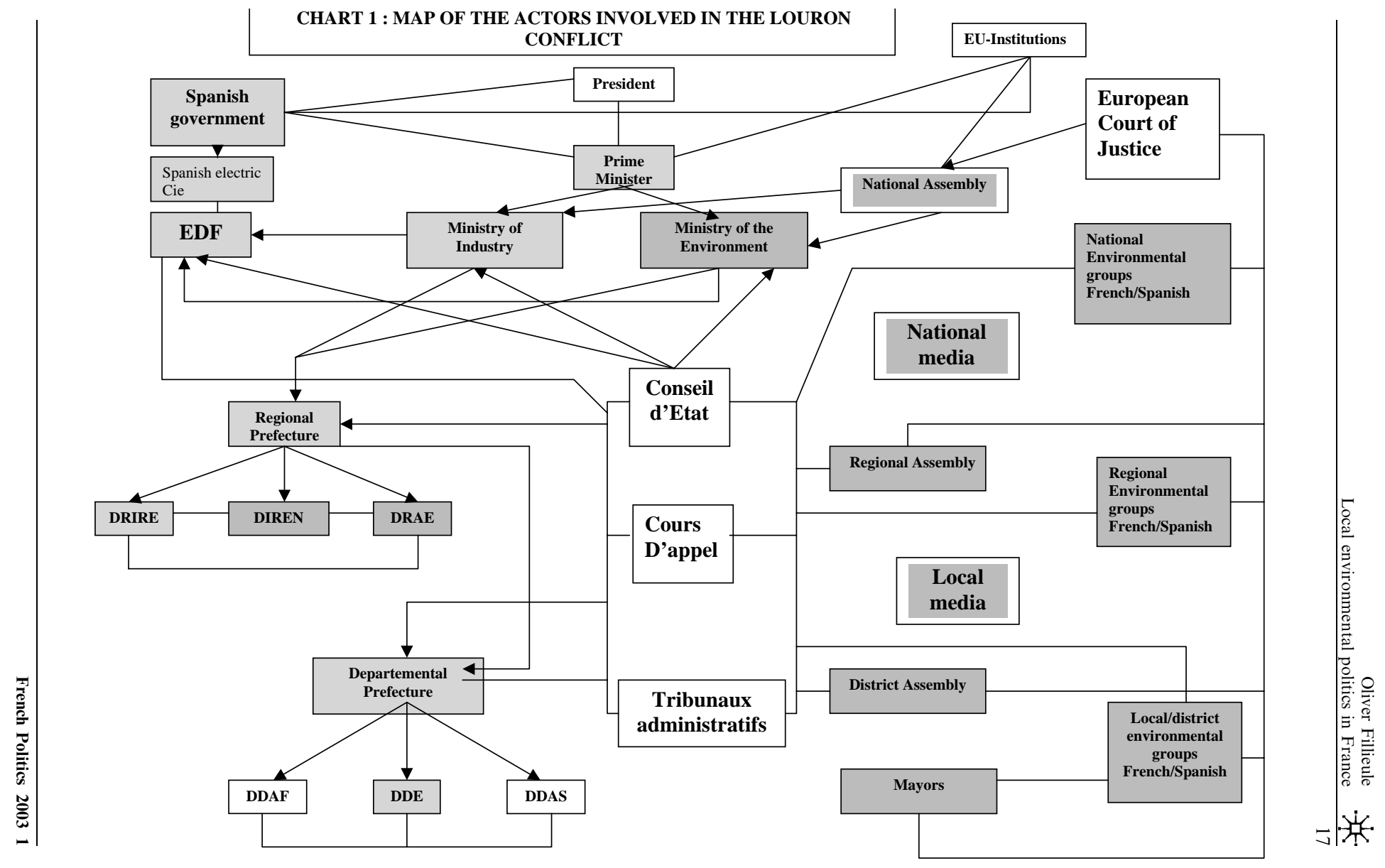
decision-makers at EDF or SNCF (Ecoles des Mines and of the Ponts et chaussées).

In fact, it is the cognitive approaches to public policy that provide conceptual instruments that can go beyond the cut-and-dried definitions of social movements as groups of actors opposed to the government. ${ }^{9}$ The notion of advocacy coalitions, first, coined by Sabatier (1987) to designate public policy coalitions and to highlight contextual factors that influence the alliances, is highly useful in that it leads to thinking of the protest fields of alliances as patterns structured in social-political networks oriented by a defined action for a given period of time ending with the accomplishment of the collective objectives. Likewise, the policy network concept (Kenis and Schneider, 1991) enables us to qualify the relations in the State/civil society cleavage by pointing out the diversity of the actors involved in the defense of a cause and the relatively fluid character of the thus-constituted groups.

McCarthy et al. (1991), through the observation of a strong tendency toward structural uniformity among American SMOs, stress the importance of channeling mechanisms in determining the emergence, forms, action repertoires and the chances of success of collective action. They thus show how legal dispositions can contribute to defining a field of strategic and tactical possibilities for movements. This attention to the indirect ways of government control is an indispensable complement to the numerous works that have analyzed direct means of control. ${ }^{10}$ It will be argued here that this dependence of movements on institutional means should be considered in a dynamic way in terms of interdependence. Under certain conditions, movements can contribute to a lasting modification of the rules of the game and consequently the set of channeling mechanisms defined by the state; in other words, the way it both facilitates and constrains collective action. The field of territorialized environmental mobilizations provides a paradigmatic illustration. The considerable increase of development conflicts in the last 20 years in Europe ${ }^{11}$ and in the USA ${ }^{12}$ has clearly contributed to a thorough redefinition of the ways in which the representatives of the State as well as planners undertake the major development projects.

In the case of France, many public policy analyses have convincingly shown how, influenced by the growing power of the mobilizations around highway constructions, TGV routes, airports and EHV lines, the paradigm defining the implementation of public policies has been transformed (Jobert, 1992, 1998; Muller, 1992, Fourniau, 1996; Ollivro, 1997; Leborgne, 1999; Blatrix, 2000). The authors agree on the distinction among the three main models of public action in infrastructure construction: the system of commands, the system of planning and the system of participation.

In the first period (1945-1970), public action featured the centrality of the State marked by the monopoly of professional expertise and an 
implementation of policies decided in a sovereign manner in conjunction with the planners at the highest level (EDF, SNCF, ADP, etc.). This system of commands is based on a social consensus around the necessity for modernization and technical progress. The policy of highway construction is the paradigmatic illustration. In this framework, technical expertise does not concern itself with dialogue with local officials or consultation with the people concerned. The State alone, through its main engineering institutions, is in a position to define the general interest.

In the 1970s, faced with new middle classes and new social movements (in particular the anti-nuclear), quality-of-life issues and environmental problems brought about by new infrastructures were beginning to be taken into account by decision-makers. The emergence of projects such as the high-speed train (TGV), and in particular the construction of the south-east TGV (between 1969 and 1977), provide a paradigmatic example through the broadening of public inquiries prior to starting the projects. This new regime of action took into account the fact that divergent points of view could coexist, which meant that the monopoly of expertise and the definition of the general interest were challenged. Moreover, the delimitation of the groups legitimately concerned by development projects grew from the owners threatened by expropriation to a set of actors including suitable environmental associations and local officials. The associations thus rose to the status of authorized actors of public development and environment policies (Lascoumes, 1994). This is the context in which the law on the protection of nature (1976) called for impact studies for any new infrastructure project and that the law on the democratization of public inquiries widened the functions of prior consultation. Nevertheless, technical-economic legitimacy, which places the definition of the general interest with the developers, still prevails.

As of the 1980s, land-use planning finally 'really became political' (Jobert, 1998) with the empowerment of protest movements, and local officials, soon to be invested with new powers but also new responsibilities by the decentralization laws. There was also a new possibility for opponents to lodge protests with European institutions (Fillieule and Ferrier, 2000). In the late 1980s to counter accusations of a democratic deficit and the development of protests, a series of legislative and reglementary dispositions were taken in an attempt to respond to this new situation. Two important steps should be mentioned: the Bianco paper of 15 December 1992, the result of a mission on transport infrastructure based on a questioning of the general interest and the issue of citizen participation in decisions in the highly problematic context of the impasse regarding the Mediterranean TGV (Ollivro, 1997; Blatrix, 2000). The procedure set up a public debate prior to studies of a planned route on both the feasibility and the social-economic stakes of major transportation projects. In addition, a continuous public consultation process was set up. The paper 
spoke of dialogue as a modern form of consultation. Then, on 2 February 1995, the Barnier law was passed, 'concerning the reinforcement of environmental protection.' Its aim was to correlate all the previous measures. It brought the public into development decisions at an earlier stage by creating a National Commission of Public Debate (CNDP). The commission was not set up to reach a consensus but to provide a forum: 'It encouraged the expression of all the arguments so as to examine them all and thus provide decision-makers with a precise picture not of public opinion (because the arguments would still have to be weighed), but of the 'argument landscape' itself. ${ }^{, 13}$ The first debate was organized on the Port 2000 project in Le Havre and the second on the Boutre Carros EHV line on the Côte d'Azur in France (Leborgne, 1999). As for EHV lines, it is important to mention the signature of an unprecedented agreement between the State and EDF for 'the installation of electric lines in the environment' (1992). Updated in 1997 in Lascoumes and Valluy (1996), this new, voluntary, agreement sets two important principles: the indemnization of local bodies by funding underground medium tension lines for EHV structures and also by credits to finance local activities; the indemnization of inhabitants of new electrical structures for 'visual harm.' The right to indemnities was extended from property owners only to a less limited set of individuals who could claim harm. This shows how far the system of compensation leads (Jobert, 1998), in that it contributes to redefining the connection between individual interests and the general interest. Invoking the general interest is thus no longer enough to demand the sacrifice of individual interests.

This is in a context of the deep changes in the ways the State manages development and land-use conflicts and in political occasions in which the Louron affair developed. It is thus easier to understand the obvious effectiveness of the rhetoric of participation (see Table 1) and the interest the successive governments showed, after a first phase of resistance without concessions, in 'patching up' the democratic deficit in the installation decision by postponing the decision time after time until the final yielding to protesters' pressures. This is undoubtedly one of the explanations of both the length of the conflict and its fortunate result for the protesters.

\section{Conclusion}

The Louron conflict provides yet another illustration that the field of social conflicts in France and probably in other countries as well has been shaped by a series of structural transformations that help to redefine the rules of the game by the appearance of new constraints as well as previously inexistent opportunities. (see also Blatrix, 2000; Hayes, 2000).

As McCarthy et al. (1991) suggest, legal provisions regulating the activity of social movements explicitly aim to channel them and restrict their repertory of 
action. From this standpoint, it is worth asking what effects the development of 'public debate' and 'participatory democracy' have had on the mobilizing capacity of environmental associations. On the basis of the case explored here, as well as from what we know of similar cases, we can point out two types of new constraints.

First, the realm of political possibilities open to movements has shrunk. Protesters are placed in a situation of having to agree to a dialogue the terms and boundaries of which are defined in advance. As a primary consequence, it becomes very difficult to dispute the actual wisdom of the projects, limiting the scope of the debate to mere details of implementation. As Blatrix rightly points out, 'whereas the texts governing public inquiry do not specify the scope of what can be debated, the Bianco circular suggests that the definition of the topic of the debate should be both vague and negotiable, but the Barnier law later delimited it in a much stricter manner. The result is that the object of the debate is now well specified (...) But the result of these texts is also that for the first time associations and the public at large are clearly denied the right to challenge the very principle or appropriateness of the project, this coming under the authority of elected officials and public authorities alone' (Blatrix, 2000, 404).

Lastly, the State's establishment of consultation procedures aims explicitly to prevent any claim of lack of transparency in expertise and thereby contributes to maintaining the fiction that in the production and discussion of expert knowledge each protagonist is equal. But the weapons the protagonists have, are not generally equal in power. This means, first of all, that the required resources for action have probably changed, money and legal and scientific expert capacity more and more often replacing strategies of numbers or public disturbance. Secondly, given that these resources are particularly difficult to unite, there is a good chance that a whole array of social groups, not to mention causes, will gradually be excluded from the arena of political protest. Indeed, if Ollitrault (1996) is right in underscoring the growing importance in environmental associations of the role exercised by people working in the educational and scientific sectors, we must immediately add that their propensity to invest in such and such a cause is first of all linked to the social logics of their geographical setting and, to take only one example, the phenomenon of neo-ruralism does not affect all areas in France in the same way. Thus, we could play the game of taking a map of France and hollowing out the areas that are both 'without qualities' and inhabited by communities that are highly unlikely to have available one day the necessary weapons to fight development. We would see rather clearly that the resulting 'negative' image would cover the current or planned localization of infrastructures such as nuclear waste burial sites, incinerators, etc. 
We will conclude by pointing out to what extent the French context is more specifically marked by a profound transformation in the relations between the State and social movements. Fights over major development projects are practically an ideal-typical illustration owing to the growing preponderance of the interdependencies that come together at the supranational level, with the European administrative, legal and political authorities and, at the regional level, with the departmental and local authorities given the considerable reinforcement of legitimacy of the local elected officials and their interest to act. Indeed, not only have the decentralization laws for a long time now organized a transfer of powers from ministries to local officials, the effects of which can be felt in many areas. Also, as was the case in the past when elected officials fought to obtain this or that major infrastructure for their area, locally situated combats are becoming a means of accumulating political capital that they can hope to convert one day into voter support.

In sum, the central role of the State in social conflicts is being gnawed away at both ends, and the image of France as a 'strong state with centralized decision-making processes,' to use the typology most often employed in comparative studies on European social movements (Kitschelt, 1986, Kriesi et al., 1995) is probably gradually losing its relevance.

\section{Notes}

1 We thank the two anonymous reviewers of French politics for their insightful comments. This article is derived from a larger research project on the Transformation of Environmental Activism (TEA, EC Contract) that was carried out from 1997 to 2001 and coordinated by Christopher Rootes, to whom we owe our interest in and knowledge of environmental mobilization.

2 The request for registering Louron was made in 1982 by the regional architecture and environment department (DRAE) in exchange for permission to develop a ski resort (Peyragude).

3 The administrative procedure for an EHV line occurs in two phases: EDF first produces an impact study and a justification of the route. They must also file a request with the prefect asking for authorization to carry out topographic operations on private property. Then EDF asks for a declaration of public utility for the work (DUP) and the regional department of industry and research (DRIR) consult the regional and departmental administrations, the town halls and the minister of industry takes the DUP, which opens the way to the signing of building permit.

4 As a reminder, in August 1991, a high tension pylon of the Pragnères Biescas line was dynamited. The perpetrators were never found out. The No Pasaran! group was implicitly accused by the press (La Dépêche du Midi, 26 August 1991).

5 See Walsh (1981, 1988), Jasper (1990) and Joppke (1993) on opposition to nuclear plants; Gamson (1992) on injustice frames, Snow and Benford (1988, 1992), Snow et al. (1986) on frame analysis and more generally Klandermans (1997) and Jasper (1997). 
6 It is undeniable that land development conflicts most often mobilize, at least at first, the people directly concerned, that is the inhabitants; but would the far-fetched idea occur to anyone to delegitimize the civil rights, unemployed, feminist and other movements on the pretext that they are first mobilizing the people directly concerned by the cause they defend? In fact, as the terms of the fight are themselves its stakes, good science should always guard itself from taking up indigenous categories. From this point of view, while the NIMBY category is a subject of study, it cannot in any case be transformed into a category of sociological analysis. For a critical appraisal of the NIMBY label, see Lafaye and Thévenot (1993, 500-502), Wolinsk (1994), Lascoumes (1994, 230-235), Gordon and Jasper (1996), Lolive (1997a,b, 1999), Trom (1999) and Blatrix (2000).

7 'How is it possible, in the blink of the eye, against unanimous public opinion, to sacrifice the landscape to economic speculation, and a risky one at that? The answer is simple. No one dares defend an aspect of France's cultural heritage - its landscape - that cannot be valuated in monetary terms. That it has a touristic potential unique in the world is forgotten. That it is a secular cultural and social asset, not a word. That it has an irreplaceable usage value, no one cares. Bureaucrats in the culture, planning, or environment ministries feel no responsibility for the 'setting.' France has an energy exportation policy today. It still does not have a landscape policy. Tomorrow, probably, in spite of the mountain dwellers' increasing demonstrations, other lines will be launched throughout the valleys. For example, between the interconnection posts of Marsillon in France and Orcoyen in Spain, still bereft of EHV lines. Watch out this time for the region of Pau. Spain is entering Europe. The Pyrénées are no more.' (Le Monde, August 20, 1985, 17). See also Le Monde (Michel Godet and Jacques Mistral - teachers at the CNAM and at Sciences Po), 14 August 1986.

8 Local elected officials are typically distrustful of environmental protection associations. This goes back to a urban/rural opposition and contradictory representations of natural space, traditional for the officials and new for the ecologists, rurbans and vacationers, who see nature and landscape as a playground. This is clearly put forward by the mayor of Mont (40 inhabitants) in the Louron, and mobilized against the line: 'the ecologists put forward dubious and biased things. I don't mind making gestures but I don't intend to be ridiculous... City ecologists can be dangerous: rural areas must not be transformed into zoos. Man has always shaped nature. There's nothing I hate more than abandoned fields and farmers deserting the valleys.'

9 See for example Tilly who defines a social movement as 'a continuous series of interactions between the holders of power and those who defy them (the latter claiming to speak for a group devoid of formal representation)' (Tilly, 1984; Tarrow, 1994, 4).

10 That is, mainly repression. See Marx (1974, 1979); Fillieule (1997), Della Porta and Reiter (1998).

11 For example, the deep changes in Great Britain in transportation policy analyzed by Dudley and Richardson (1998) who analyzed the deviation of the official procedure of highway inquiries that was supposed to frame the interests involved in arenas without rules by protesting groups.

12 Gordon and Jasper write about America that 'in poor neighborhoods as well as rich, in rural areas as well as urban, local opponents ... are standing up to developers, large corporations and federal, state and local governments. They have been remarkably successful, for example blocking virtually all proposals for new hazardous waste facilities during the 1980s (Mitchell and Carson, 1986). These groups are changing, among other things, the shape of environmental politics' $(1996,160)$.

13 Porcell, report of the public debate, October 1998, 43, in Leborgne $(1999,159)$. 


\section{References}

Anderson, A. (1997) Media Culture and the Environment. UCL Press.

Blatrix, C. (2000) La 'démocratie participative,' de mai 1968 aux mobilisations anti-TGV. Processus de consolidation d'institutions sociales emergentes' Thèse pour le doctorat de $\mathrm{III}^{\circ}$ cycle, université Paris I, typescript.

Catherin, V. (2000) La contestation des grands projets publics. Analyse microsociologique de la mobilisation des citoyens, Paris: L'Harmattan.

Cottle, S. (1993) TV News, Urban Conflict and the Inner City, Leicester University Press.

CRESAL. (1993) Les raisons de l'action publique. Entre expertise et débats, Paris: L'Harmattan.

Della Porta, D. and Reiter, H. (eds.) (1998) Policing Protest. The Control of Mass Demonstrations in Western Democracies, Minneapolis: University of Minnesota Press.

Della Porta, D. and Rucht, D. (eds.) (2002) 'Comparative environmental campaigns', Mobilization $7(1)$.

Dudley, G. and Richardson, J. (1998) 'Arenas without rules and the policy change process: outsider groups and the British road policy', Political Studies 46(4).

Fillieule, O. (1997) Stratégies de la rue. Les manifestations en France, Paris: Presses de Sciences Po.

Fillieule, O. and Ferrier, F. (1999) 'Ten years of environmental activism in france' et 'Selection bias in the French database on protest events', ECPR, Mannheim, mars 1999.

Fillieule, O. and Ferrier, F. (2000) 'Between the market and the state. French environmental organisations', Paper given to the Copenhagen ECPR Conference.

Fillieule, O. and Jimenez, M. (forthcoming) 'Media bias and environmental protest event analysis', in Ch Rootes (ed.), Environmental Mobilization in Comparative Perspectives, Oxford: Oxford University Press.

Fourniau, J.M. (1996) 'Transparence des décisions et participation des citoyens', Techniques, Territoires et Sociétés, Prospective sciences sociales, Projets d'infrastructures et débat public, Ministère de l'aménagement du territoire, de l'équipement et des transports, no. 31, mai 1996, pp. 9-48.

Freidman et al. (1987) 'Environmental reporting. The role of local newspapers', 29(2): 4-45.

Gamson, W. (1992) Talking Politics, New York: Cambridge University Press.

Giugni, M., McAdam, M. and Tilly, Ch (eds). (1999) How Social Movements Matter, Minneapolis: University of Minnesota Press.

Gordon, C. and Jasper, J. (1996) M 'Overcoming the NIMBY label: rhetorical and organizational links for local protestors', Research in Social Movements, Conflicts and Change 19: 159-181.

Gusfield, J.R. (1986) Symbolic Crusades. Status Politics and the American Temperance Movement, Illini Books edition (1st ed in 1963).

Hayes, G. (2000) 'Political opportunity structure and environmental protest in the French Fifth Republic' Unpublished Ph.D. dissertation University of Manchester.

Jasper, J.M. (1990) Nuclear Politics: Energy and the State in the United States, Sweden and France, Princeton, NJ: Princeton University Press.

Jasper, J.M. (1997) The Art of Moral Protest. Culture, Biography, and Creativity in Social movements, Chicago and London: The University of Chicago Press.

Jobert, A. (1998) 'L'aménagement en politique ou ce que le syndrome NIMBY nous dit de l'intérêt général', Politix (42): 67-92.

Jobert, B. (1992) 'représentations sociales, controverses et débats dans la conduite des politiques publiques', Revue française de science politique 42(2): 219-234.

Joppke, C. (1993) Mobilizing Against Nuclear Energy, Berkeley: University of California Press.

Kitschelt, H. (1986) 'Political opportunity structures and political protest: anti-nuclear movements in four democracies,' British Journal of Political Science 16: 57-85.

Klandermans B. (1997) The Social Psychology of Protest, London: Blackwell Publishers. 
Kriesi, H., Koopmans, R., Duyvendack, J.W. and Giugni, M. (1995) The Politics of New Social Movements in Western Europe, Minneapolis: University of Minnesota Press.

Lafaye, C. and Thévenot, L. (1993) 'Une justification écologique? Conflits dans l'aménagement de la nature'. Revue française de sociologie 34(4): 591-607.

Larue, C. (2000) Analyser les politiques publiques d'environnement. Paris: L'Harmattan.

Lascoumes, P. (1994) L'éco-pouvoir. Environnements et politiques, Paris: la Découverte.

Lascoumes, P. and Valluy, J. (1996) 'Les activités publiques conventionnelles (APC). Un nouvel instrument de politique publique? L'exemple de la protection de l'enviornnement indissutriel', Sociologie du travail 37(4).

Leborgne, M. (1999) 'De quelques caractères associatifs. La mobilisation associative entre l'élu local et le citoyen lors du débat public relatif au projet de ligne THT entre Boutre (Var) et Carros (Alpes Maritimes)', in CRESAL: Dynamique et fonctionnement des associations de protection de la nature et de défense de l'Environnement, Travaux de recherche, rapport dactylographié pour le Ministère de l'environnement (DGAD/SRAE), Vol 1, Juillet 1999, pp. 151-191.

Lolive, J. (1997a) 'La montée en généralité pour sortir du NIMBY', Politix (39): 109-130.

Lolive, J. (1997b) 'La mise en œuvre controversée d'une politique de réseau: les contestations du TGV méditerranée' thèse de doctorat en science politique, Université de Montpellier I, typescript.

Lolive, J. (1999) Les contestations du TGV méditerranée, Paris: L’Harmattan.

Mabileau, A. (1993) Le système local en France, Paris: Montchestien.

Marin, B. and Mayntz, R. (eds.) (1991) Policy Networks. Empirical Evidence and Theoretical Considerations, Boulder: Westview Press.

Marx, G.T. (1974) 'Thoughts on a neglected category of social movement participant: the agent provocateur and the informant', American Journal of Sociology (80): 402-442.

Marx, G.T. (1979) 'External efforts to damage or facilitate social movements: some patterns, explanations, outcomes and complications', in J. McCarthy and N. Zald. (eds.) The Dynamics of Social Movements, Cambridge MA: Winthrop Pub, pp. 94-125.

Marx, G.T. (1988) Undercover: Police Surveillance in America, Berkeley: University of California Press.

McCarthy, J.D., Britt, D.W. and Wolfson, M. (1991) 'The institutionnal channeling of social movements by the state in the United States', Research in Social Movements, Conflict and Change 13: 45-76.

Mitchell, R.C. and Carson, R.T. (1986) 'Property rights, protest and the siting of hazardous waste facilities', American Economic Review 76: 285-290.

Moloch, H. and Lester, M (1975) 'Accidenta inews: the great oil spills as local occurrence and national event', American Journal of Sociology 81: 235-260.

Muller, P. (1992) 'Entre le local et l'Europe. La crise du modèle français des politiques publiques', Revue française de science politique 42(2).

Ollitrault, S. (1996) 'Action collective et construction identitaire: le cas du militantisme écologiste en France' Thèse de sciences politique, Université de Rennes I.

Remy, E. (1995) ‘Apprivoiser la technique, débat public autour d'une ligne à haute tension', Politix (31): 136-144.

Sabatier, P.A (1987) 'Knowledge, policy-oriented learning and policy change. An advocacy coalition framework', Knowledge 8: 649-691.

Sandman, P.M. et al. (1987) Environmental Risk and the Press, an Exploratory Assessment, New Brunswick, NJ: Transaction Books.

Sawicki, F. (1997) Les réseaux du parti socialiste, Sociologie d'un milieu partisan, Paris: Belin.

Singh, R. et al. (1989) 'Mass media and environmental issues, a case of India', Paper for the Conference of the IAMCR.

Snow, D.A. et al. (1986) 'Frame Alignment Processes 'Micromobilization' and Movement Participation', American Sociological Review 51: 464-480. 
Snow, D.A. and Benford, R. (1988) 'Ideology, frame resonance, and participant mobilization', International Social Movement Research 1: 197-217.

Spears, et al. (1987) 'Sources of evaluation of nuclear and renewable energy contained in the Local Press,' Journal of Environmental Psychology 7: 31-43.

Tapie-Grime, M. (1997) 'Le NIMBY, une ressource de démocratisation', Ecologie et politique 21.

Tarrow, S. (1994) Power in Movement, Social movements, Collective Action and Politics, Cambridge: Cambridge University Press.

Tilly, C. (1984) 'Social movements and National politics', in C. Bright, and S. Harding, (eds.) Statemaking and Social Movements: Essays in History and Theory, Ann Arbor: University of Michigan Press, pp. 297-317.

Trom, D. (1999) De la réfutation de l'effet NIMBY considérée comme une pratique militante. Notes pour une approche pragmatique de l'activité revendicative', Revue Française de Science Politique (49): 31-50.

Valluy, J. (1994) 'Peut-on éviter les NIMBY ? Expériences américaines et canadiennes relatives aux installations d'élimination des déchets industriels dangereux', Electricité et société (17): 34-37.

Valluy, J. (1996) 'Coalition de projet et délibération politique: le cas du projet d'implantation de décharges de déchets industriels dans la région Rhône-Alpes (1979-1994)', Politiques et management public 14(4): 101-131.

Valluy, J. (1999) 'Le gouvernement partenarial. Etude de la prolifération des activités de gouvernement conventionnelles (AGC) dans deux configurations de politique publique de l'environnement en France' thèse pour le doctorat en science politique, IEP Paris, dactylographié.

Walsh, E.J. (1981) 'Resource mobilization and citizen protest in communities around three miles island', Social Problems 29: 1-21.

Walsh, E.J. (1988) Democracy in the Shadows, New York: Greenwood Press.

Wolinsk, M. (1994) Entanglement of interests and motives: assumption behind the NIMBY theory on facility setting', Urban Studies 31(6). 